hors de lordinaire, leur indiquer la voie à suivre et éliminer les obstacles sur leur chemin. En ce sens, le bureau de direction nationale a bien travaillé cette année. Avec le concours de notre directrice générale, Dana Collins, et celui du conseil d'administration de l'Institut, nous avons consacré beaucoup de temps à définir et à mettre en place les orientations stratégiques qui nous auront permis datteindre nos objectifs.

Nous avons retenu cinq domaines stratégiques principaux et $\mathrm{y}$ avons consacré tous nos efforts pour maximiser les résultats. Voici donc les réalisations de cette année dont nous sommes très fiers :

1. Représenter une valeur ajoutée pour nos membres par la réalisation d'un programme efficace de formation continue et de croissance professionnelle en foresterie. Nous avons fait preuve de leadership en matière de communication en foresterie (entre autres avec les infographies sur « Le mythe de la déforestation " et "Les bienfaits de la foresterie urbaine », organisé plus de 40 conférences électroniques, avons publié le Chronicle, élaboré un programme de formation complémentaire pour l'OPFA et avons été choisi comme mandataire du programme de marquage des arbres pour les projets sylvicoles de l'Ontario.
2. Assurer la stabilité financière de l'IFC/CIF en augmentant le nombre de membres (individuels et organisationnels) et en visant un excédent budgétaire annuel. Nous envisageons d'atteindre (ou de dépasser) nos objectifs budgétaires par une diversification des revenus, une gestion budgétaire prudente effectuée sous la direction par le comité des Finances et avons réussi à accroître notre fonds de réserve grâce à un modeste excédent annuel.

3. Promouvoir le professionnalisme en étant le principal forum par excellence pour relier entre eux les professionnels de la foresterie, les praticiens, les enseignants et le public concerné par l'environnement (incluant les jeunes). Nous participons activement à lélaboration d'excursions techniques pour les enseignants ainsi quau programme Envirothon et nous continuons de donner l'exemple avec notre nouvelle philosophie sur les joncs d'argent qui vise à unir les membres de la profession.

4. Être reconnu au plan national et international comme la voix officielle de la foresterie au Canada. Nous avons développé nos relations avec la Chine, les É.-U. et le R.-U. et pour la première fois, nous avons créé une section internationale dont le directeur est invité aux réunions du conseil d'administration. Cette plus grande visibilité a fait en sorte que l'Agence internationale de l'Énergie a retenu l'IFC/CIF pour élaborer et coordonner une série de webinaires de portée internationale.

5. Promouvoir la sensibilisation à l'importance de la foresterie au sein du public en étant visible, informé et pertinent à ses yeux. Nous avons coordonné quelque 200 activités et la distribution de plus de 15000 affiches dans le cadre de la Semaine nationale de larbre et des forêts, préparé des communiqués de presse, des éditoriaux et d'autres textes, en plus davoir fait tourner une publicité lors du Grand Prix de Montréal.

De plus, nous avons reformulé la politique de gouvernance de l'IFC/CIF afin dêtre plus efficaces et efficients dans notre façon de travailler et ainsi nous permettre déviter les écueils administratifs. Même s'il ce n'est pas le sujet le plus passionnant-c'est celui qui apporte le plus d'avantages durables pour l'Institut, pour les membres de son conseil d'administration et pour le personnel de l'IFC/CIF.

Je suis fier de ce que nos réalisations de la dernière année et j’ai hâte de vous rencontrer tous lors de la conférence de Vancouver en septembre!

\title{
㴶 How to Write a Journal Article: Tips and Tools
}

\author{
Sarah Boon, Ph.D. ${ }^{1}$
}

If you've trained as a scientist, you know that part of the learning curve involves figuring out how to write a scientific paper. Unfortunately, few scientists receive explicit instruction in writing papers-researchers by definition are expected to know how to write. When you're a grad student, your supervisor is there to guide you through the paper publication process, as it's in their best interests to have you publish the outcome of your research with them. Once you become an independent scientist, however - whether that's in academia, industry, or at an $\mathrm{NGO}$-writing research papers can be a frustrating and lonely experience.
There are many online resources and excellent books designed to provide writing advice to scientists. The difficulty as an early career researcher lies in making the time to learn how to write a good paper while also teaching yourself $\mathrm{R}$ stats and maybe a bit of Bayesian statistical methods, coming up with new pedagogical approaches to engage your studentsor figuring out how to manage a work team, applying for a shrinking pot of grant funds, starting up a lab or getting familiar with a new job.

This post distills the process of writing a paper into the key steps, and provides links to additional resources available.

${ }^{1}$ Sarah Boon blogs at Watershed Moments about nature, nature writing, science communication, and women in science. She is a member of the Canadian Science Writers' Association and the Editors' Association of Canada, and was elected a Fellow of the Royal Canadian Geographical Society in 2013. Sarah is also a founding member of Science Borealis. Find Sarah on Twitter: @SnowHydro 
The goal is to give you a good head start on writing your next scientific paper, while providing specific places to find more detailed advice.

\section{Before You Start Writing}

The key to writing a successful research article begins well before you even put pen to paper. While you're doing background reading about your research area, it can be useful to save journal articles in a reference management system such as Mendeley, Zotero, or Endnote. This will help you keep track of all the papers related to your research, and make it a lot easier to create reference lists for future research papers. Secondly, you want to ensure that the design of your research project includes a well-defined research goal and series of objectives, as this forms the foundation of your research paper. Thirdly, a good paper requires that you maintain excellent notes of the materials you used and the methods you applied to answer your research question, so that readers can replicate your experiment if they so choose. Finally, many scientists suggest that you only start writing once you've completed all of your analysis, and have created a series of key plots and tables that best support your research goal and objectives. This will give you a strong narrative to follow in outlining your results and developing your discussion. Once you have these aspects together, you should be ready to sit down and write.

\section{Research Paper Structure}

A typical research paper is divided into nine sections: Title and Abstract, Introduction, Materials and Methods, Results, Discussion, Conclusion, Acknowledgements, and References. If you do fieldwork, you may have an additional Study Site section between the Introduction and Materials and Methods sections.

\section{Title and Abstract}

Scientists read the title and abstract to decide whether or not they will delve into an entire paper-so you want to make sure to grab them right away! The key is to write these after the paper is completed. That way you can come up with a catchy title and structure the abstract as a mini-paper, with the research question and context, the key results and the new things those results tell us, how it compares with other research, and a conclusion for further work.

\section{Introduction}

This section is all about placing your work into the broader research context, and then narrowing your focus to identify specifically what you plan to do in the paper: i.e., your research goals and objectives.

\section{Materials and Methods}

You want to provide enough detail that someone else could replicate the study if need be, and outline your rationale for that approach. Lay out what you did step by step, from the beginning to end of your experiment. Include not only how and why you collected data, but also how and why you applied specific analysis techniques. It can sometimes be hard to determine how much information is too much information; a good piece of advice is to put in more than you need, as you can always pare it down later.

\section{Results}

As Ivan Valiela says in his book, Doing Science, this section tells the reader "the facts revealed by your work." For example, a colleague is currently working on a paper that includes these subheadings in the Methods section: experimental design, logging history, environmental monitoring, and data analysis. The results section outlines observed weather and snowpack conditions (based on the environmental monitoring), and describes changes in streamflow with logging quantified by applying specific data analyses to the streamflow data (part of the environmental monitoring), in relation to the specific experimental design.

\section{Discussion}

The discussion is where you pull your results together into a coherent story, and put that story in context by referring back to your own results and to other peoples' research. By the end of the discussion, you should have addressed the goals and objectives you outlined in your introduction.

\section{Conclusion}

The conclusion ties up the paper by reiterating the research question, restating the significant results and the story they tell, and identifying any areas for further research.

\section{Acknowledgements and References}

Always be sure to recognize the contributions of others to your research, whether they're assistants, funding agencies, or colleagues who helped you talk through different aspects of your work. As for the references-this is where the reference management system we talked about previously comes in, as it should make it relatively easy to create your reference list.

\section{Other Tips}

Don't assume you have to write the paper in order from start to finish. You may find it easier-as many scientists do-to start with the Results section, referring to your tables and figures to explain what's happening. Others may find it easier to start with the Methods section, writing out what they did and why. Still others may start with the Introduction, as it helps them mentally set the stage for what they need to write next.

Don't wait for the perfect sentences to arrive in your mind before you start typing. Remember, everyone writes a crappy first draft, but it gives you something to work with on the path to writing your final paper. I also recommend that scientists who struggle with writing - and even those who don't-hire a professional scientific editor. While some researchers may think this is "cheating" or an admission of failure, it's similar in scope to hiring yourself out as a consultant in a particular research field. You can hire an editor for anything from just proof-reading, to improving overall paper structure, to working at the intermediate scale of improving paper wording and flow. Whatever services you need, there's an editor out there who is trained to provide them.

\section{Additional Resources}

- Over on the LSE Impact Blog, Patrick Dunleavy explains why the title of your paper is so important-and gives advice on how to come up with the best title possible.

- This post by Pat Thomson (also on the LSE Impact Blog) focuses specifically on writing an introduction. She reiterates the point above that a good introduction will make people want to keep reading your paper, and shows you how to get there.

- This post over at Methods Blog provides an "Alternative Guide to Authors" by detailing what you should include in each paper section. I particularly like their SUCCES acronym, which provides general principles of how to get 
your message across to the reader. The last $\mathrm{S}$ stands for "story"- just as we've described above.

- Over on Dynamic Ecology, Brian McGill has an excellent post that goes beyond the standard paper outline to identify the five key paragraphs in a paper: the first and last paragraphs of the introduction, the first and last paragraphs of the discussion, and the abstract. If you're having trouble getting the sections of your paper to flow together, McGill has some good advice for you.

- If you're having problems writing paragraphs, then this post from Writing For Research is for you. They talk about the six things that usually go wrong in writing paragraphs-such as starting with a reference to another paper, or writing paragraphs that are too short or too long. Luckily, they also provide advice on how to fix these problems.

- Doing Science, by Ivan Valiela, has an excellent chapter on Communicating Scientific Information: The Scientific Paper.
He advocates for starting with the Results section when writing a paper, and provides prudent advice on dealing with all other paper sections.

- Canadian scientist (and FACETS editorial board member) Stephen Heard released The Scientist's Guide to Writingloads of great writing advice for both new and experienced scientists. Finally, if you're trying to figure out how best to visualize your results, I recommend any book by Edward Tufte (e.g., The Visual Display of Quantitative Information or Envisioning Information). He's a master of data visualization, and can help you come up with new ways to show your data that make writing the Results section a breeze.

(This article is reproduced with permission from Canadian Science Publishing; the original article is available at: http://www.cdnsciencepub.com/blog)

\section{NATIONAL/INTERNATIONAL NEWS * NOUUELLS NATIONALES/INTERNATIONALES}

\section{Diploma to Degree Agreement between Fleming College and UBC}

raduates of southern Ontario's Flem5 ing College's Urban Forestry Technician (UFT) Co-op program now have the option of completing a Bachelor of Urban Forestry degree at the University of British Columbia (UBC). An agreement signed in early May between UBC's Faculty of Forestry and the UFT program allows eligible graduates of the two-year diploma program to finish their degree with three additional years of study at UBC.

"We are delighted that Fleming College's Urban Forestry Technician Co-op program saw value in partnering with UBC Forestry in this area. Our new program is already proving to be very attractive and, like our other undergraduate programs, would benefit from a flow of experienced students entering the program mid-stream. We look forward to developing this relationship which will clearly be of benefit to the students that are involved," said John Innes, Dean of Forestry at UBC.

"UBC's Faculty of Forestry is highlyesteemed and respected. We are so pleased to announce this new partnership," said Linda Skilton, Principal of Fleming's Frost Campus and Dean of the School of Environmental and Natural Resource Sciences. "More often, students are recognizing the benefits of diploma to degree pathways. They have become a popular option for our graduates, providing them with a unique combination of applied learning and theoretical knowledge."

UBC officially launched the Bachelor of Urban Forestry degree in September 2015 to meet the growing demand for urban forest managers and urban forest planners. The new degree program is the first of its kind in western Canada.

"Urban forestry jobs have grown and continue to grow across Canada, and the industry has expressed a need for urban forestry graduates who are qualified for entry-level positions but would also be eligible for management positions that may require degree completion," said Dean Skilton.

Fleming's UFT program is located at Fleming's Frost Campus in Lindsay, Ontario and is part of the College's renowned School of Environmental and Natural Resource Sciences. The program features a paid co-operative education component, providing students with real world experience. UFT has existing 2+2 diploma-degree agreements with University of New Brunswick (UNB) and Lakehead University in which Fleming UFT graduates can complete a diploma and degree in as few as four years.
"In having these articulation agreements with UNB and Lakehead, it made sense to pursue an option on the west coast as well so that our students can choose from a variety of post-secondary options - each university degree is very different from the other," said Tom Mikel, Coordinator of Fleming's UFT program.

\section{About Fleming College \\ Located in the heart of Central Ontario, Fleming College has campus locations in Peterborough, Lindsay, Cobourg and Haliburton. Named for famous Cana- dian inventor and engineer Sir Sandford Fleming, the college features more than 100 full-time programs in Arts and Heritage, Business, Environmental and Natural Resource Sciences, General Arts and Science, Health and Wellness, Justice and Community Development, Skilled Trades and Technology, and Continuing Education. Fleming College has more than 5800 full-time and 10000 part-time students, and 68000 alumni.}

Source: Fleming College Media Release, May $11^{\text {th }}, 2016$ 